\title{
Evaluation of Nested Polymerase Chain Reaction for Detecting Myocobacterial DNA in Pleural Fluid
}

\author{
Kazuyoshi KUWANO'), Wakio MINAMIDE ${ }^{2)}$, Shinji KUSUNOKI ${ }^{2)}$, \\ Hirotsune IGIMI ${ }^{2)}$, Tetsuro FUJIKI ${ }^{3)}$, Kenichi MATSUBA ${ }^{3)}$ \\ and Nobuyuki HARA ${ }^{1)}$ \\ ${ }^{1)}$ Research Institute for Diseases of the Chest, Faculty of Medicine, Kyushu University \\ ${ }^{2)}$ Shionogi Biomedical Laboratories, Shinogi Pharmaceutical Co., Ltd. \\ ${ }^{3}$ Department of Internal Medicine, Kitakyushu Shoujuen Hospital
}

(Received: August 29, 1994)

(Accepted: November 8, 1994)

Key words: nested PCR, mycobacteria, pulmonary tuberculosis, pleural fluid

\begin{abstract}
A protocol based on the polymerase chain reaction (PCR) is the most sensitive method for detecting mycobacteria in clinical samples. However, few studies have assessed the usefulness of this method in the diagnosis of tuberculous effusion. We developed a highly sensitive and specific nested PCR method, that amplifies the bovine tuberculous MPB70 gene and the mycobacterial 16S rRNA gene for use in detecting Mycobacterium tuberculosis (M. tuberculosis) and mycobacteria, respectively, in clinical samples. We determined the sensitivity of this method for detecting mycobacteria in samples containing known amounts of mycobacterial DNA and in DNA extracted from pleural effusions obtained from 10 patients with pulmonary tuberculosis in whom standard microbiological techniques had detected mycobacteria in sputum but not in pleural effusion. The nested PCR method for the bovine tuberculous MPB70 gene and the mycobacterial 16S RNA gene was able to detect $M$. tuberculosis and mycobacterial genomes only if there were at least 2 copies per sample. Positive results for $M$. tuberculosis and the mycobacterial genomes were obtained by nested PCR in 2 of 10 and in 3 of 10 samples of pleural fluid, respectively but no mycobacteria were detected in malignant effusions obtained from 9 patients with lung cancer. The nested PCR method represents a rapid means for detecting mycobacteria in some pleural effusions previously found to be negative by cluture. We speculate that the reaction of the host against mycobacteria is more important than the mycobacteria themselves in the pathogenesis of pleural effusion in which mycobacteria are not detected.
\end{abstract}

\section{Introduction}

Attempts at direct identification of acid-fast staining are usually unrewarding. Gulture pleural fluid has a specificity approaching $100 \%$, but the growth of mycobacteria in vitro entalis a delay of 3 to 6 weeks, and gives negative results in a substantial number of cases. The polymerase chain reaction (PCR), a new technique for in vitro amplification of specific DNA segments ${ }^{1) \sim 3)}$, has been used to diagnose mycobacterial infection directly by detecting DNA of mycobacteria in clinical specimens ${ }^{4) \sim 10}$. However, a few studies have evaluated the usefulness of PCR in the diagnosis of

Correspondence to : Kazuyoshi KUWANO, M.D.

Research Institute for Diseases of the Chest, Faculty of Medicine, Kyushu University, 3-1-1, Maidashi, Higashiku,

Fukuokashi, 812 Japan

平成 7 年 2 月 20 日 
mycobacterial pleurisy when cultures were negative ${ }^{11) 15)}$. We have already reported 2 PCR methods that amplify the bovine tuberculous MPB70 gene and the mycobacterial 16S rRNA gene, for detection of $M$. tuberculosis and mycobacteria, respectively, in sputum ${ }^{16)}$. In this study, we improved our methods and developed nested PCR, which is a two step amplification, first with outer primers and then with inner primers nested within the first primers, attempting to increase both the sensitivity and the specificity of the PCR ${ }^{17)}$. This study sought to determine the sensitivity of nested PCR for the detection of mycobacterium and its utility in the diagnosing of mycobacterial pleurisy when culture had failed to detect mycobacteria.

\section{Materials and Methods}

Case Material

Samples of pleural fluid from 10 patients with pulmonary tuberculosis and 9 patients with lung cancer were studied. The diagnosis of pulmonary tuberculosis was established by sputum culture for mycobacteria in all 10 cases, and that of lung cancer was established by the cytology of pleural effusion or by the histology of pleural biopsy specimens. Mycobacterial culture failed to detect mycobacteria in any pleural effusion. Two different samples of pleural fluid from each patient were studied by the nested PCR method.

DNA extraction

One milliliter of pleural effusion was mixed with $1 \mathrm{ml}$ of distilled water and centrifuged at 10,000 $\mathrm{g}$ for $5 \mathrm{~min}$; the aqueous phase was discarded. This step was repeated twice. The samples were heated for $30 \mathrm{~min}$ at $70^{\circ} \mathrm{C}$ and incubated for $15 \mathrm{~min}$ at $37^{\circ} \mathrm{C}$ with lysozyme, $10 \mathrm{mg} / \mathrm{ml}$. The samples were homogenized with glass beads by vortexing and addition of $900 \mu \mathrm{l}$ of TE $(10 \mathrm{mM}$ Tris $\mathrm{HCl}, 1 \mathrm{mM}$ EDTA) buffer, and incubated at $37^{\circ} \mathrm{C}$ overnight. After the addition of $100 \mu$ l of $20 \%$ SDS in $0.2 \mathrm{~N}$ $\mathrm{NaOH}$, this mixture was treated with phenol/ $\mathrm{CHCl}_{3} /$ isoamylalchol $(25: 24: 1)$. After ethanol precipitation, the DNA was dried and dissolved in $100 \mu 1$ of distilled water.

PCR amplification

The nucleotide sequences of the primers are shown in Table 1 . These primer pairs amplified the $560 \mathrm{bp}$ fragment of the mycobacterial 16S rRNA gene and the $332 \mathrm{bp}$ fragment of the bovine tuberculous MPB70 gene. Outer primers are the same as those used in conventional PCR methods which we described previously ${ }^{16)}$. Five microliters of heat-denatured DNA sample was added to a solution containing $10 \mathrm{mM}$ Tris $\mathrm{HCl}(\mathrm{pH} 8.3), 50 \mathrm{mM} \mathrm{KCl}, 1.5 \mathrm{mM} \mathrm{MgCl}_{2}, 0.01 \%$ gelatin, $200 \mu \mathrm{M}$ each of dNTPs, $0.2 \mu \mathrm{M}$ each of outer primers and 1.25 units of Amplitaq DNA polymerase (PerkinElmer Cetus Co., Ltd). The total volume of each tube was $50 \mu 1$. The contents of the tube were mixed gently, covered with $30 \mu \mathrm{l}$ of mineral oil and subjected to 34 cycles of 1 min denaturation at $94^{\circ} \mathrm{C}, 1$

Table 1 Sequences of oligonucleotides used in this study

\begin{tabular}{lc}
\hline Oligonucleotide & Sequence $\left(5^{\prime}-3^{\prime}\right)$ \\
\hline Mycobacterial & 16S rRNA gene amplification primers \\
Outer primers & AGAGTTTGATCCTGGCTCAG \\
& GCCGTGAGATTTCACGAACA \\
Inner primers & TAACAAATGCAAGTCGAACG \\
& GCCGTGAGATTTCACGAACA \\
Tuberculous MPB 70 gene amplification primers \\
Outer primers & GAACAATCCGGAGTTGACAA \\
& AGCACGCTGTCAATCATGTA \\
Inner primers & CGCTGACGGCTGCACTGTCG \\
& CACCGTCGCGTTGGCGGTAG \\
\hline
\end{tabular}


min to allow annealing at $62^{\circ} \mathrm{C}$, and 1 min of extension at $72^{\circ} \mathrm{C}$. During the last cycle, the extension time was increased by $7 \mathrm{~min}$. After the first PCR, $2 \mu 1$ of the product was amplified for 20 cycles with the corresponding inner primers. The product of the second PCR was analyzed by $2 \%$ agarose gel electrophoresis with ethidium bromide staining. A sample was considered to be positive if a single band corresponding to an amplified product of the appropriate size was seen in the gel.

\section{Results}

The 2-step PCR with nested primers was more sensitive than the conventional PCR for detecting mycobacterial DNA sequences in serially diluted DNA samples (Fig. 1). Nested PCR was at least 10 times more sensitive than conventional PCR, and could detect $0.01 \mathrm{pg}$ (two copies) of genomic DNA for $M$. tuberculosis and mycobacteria. Because of the increased sensitivity, we were able to use simple agarose gel electophoresis and ethidium bromide staining.

All the pleural fluid specimens obtained from patients with pulmonary tuberculosis and lung cancer were negative for mycobacteria on direct microscopic examination and culutre. The results of PCR and the representative clinical data of these patients are shown in Table 2. A patient was considered positive if 1 of 2 different samples gave a positive result. All samples were negative by conventional PCR. However, by nested PCR, 3 of the 10 patients with pulmonary tuberculosis were positive for 16S rRNA PCR, and 2 of these 3 were also positive for MPB70 PCR. The concentrations of lactate dehydrogenase and adenosine deaminase in pleural fluid were higher in the 2 patients who

Fig. 1 Comparision of conventional and nested PCR. The amount of serially diluted $M$. tuberculosis DNA was $10^{4}, 10^{3}, 10^{2}, 10,1$ and $0 \mathrm{fg}$.

(A) Conventional PCR (1) and nested PCR (2) for the 16S rRNA gene. The expected sizes of the products were 600 and 560 base pairs, respectively. (B) Conventional PCR (1) and nested PCR (2) for the MPB 70 gene. The expected sizes of the products were 372 and 332 base pairs, respectively.

A

(1)

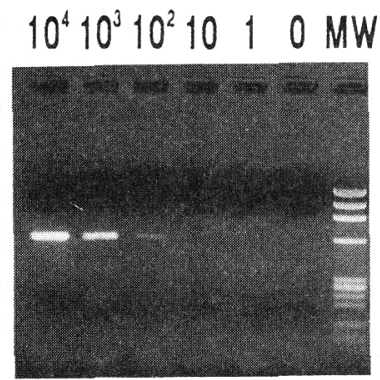

(2)
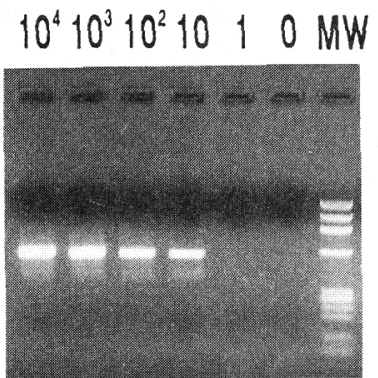

B

(1)

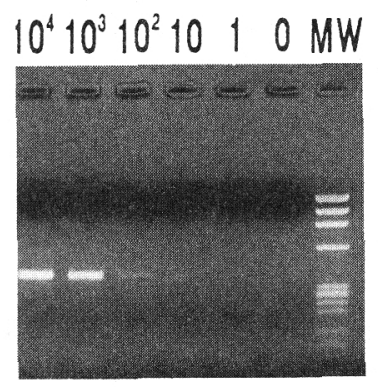

(2) $10^{4} 10^{3} 10^{2} 1010 \mathrm{MW}$

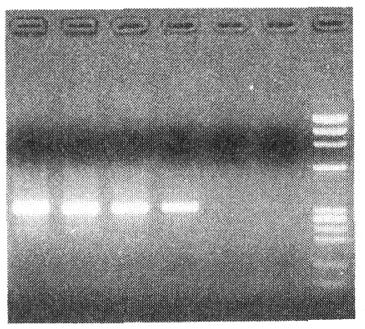


Table 2 Results of 16S rRNA PCR and MPB70 PCR and clinical data in 10 patients with pulmonary tuberculosis

\begin{tabular}{|c|c|c|c|c|c|c|}
\hline \multirow{2}{*}{ Case } & \multicolumn{2}{|c|}{$\begin{array}{l}\text { Results of } \\
\text { rRNA PCR }\end{array}$} & \multicolumn{2}{|c|}{$\begin{array}{l}\text { Results of } \\
\text { MPB70 PCR }\end{array}$} & \multicolumn{2}{|c|}{$\begin{array}{l}\text { Concentration in } \\
\text { pleural effusion }\end{array}$} \\
\hline & conv & nested & conv & nested & $\begin{array}{l}\mathrm{LDH} \\
(\mathrm{IU} / \mathrm{L})\end{array}$ & $\begin{array}{c}\mathrm{ADA} \\
(\mathrm{IU} / \mathrm{L})\end{array}$ \\
\hline 1 & $0 / 2$ & $1 / 2$ & $0 / 2$ & $1 / 2$ & 8,760 & 138 \\
\hline 2 & $0 / 2$ & $1 / 2$ & $0 / 2$ & $1 / 2$ & 2,220 & 110 \\
\hline 3 & $0 / 2$ & $1 / 2$ & $0 / 2$ & $0 / 2$ & 995 & 30 \\
\hline 4 & $0 / 2$ & $0 / 2$ & $0 / 2$ & $0 / 2$ & 285 & 38 \\
\hline 5 & $0 / 2$ & $0 / 2$ & $0 / 2$ & $0 / 2$ & 905 & 78 \\
\hline 6 & $0 / 2$ & $0 / 2$ & $0 / 2$ & $0 / 2$ & 480 & 43 \\
\hline 7 & $0 / 2$ & $0 / 2$ & $0 / 2$ & $0 / 2$ & 258 & 42 \\
\hline 8 & $0 / 2$ & $0 / 2$ & $0 / 2$ & $0 / 2$ & 1,180 & 57 \\
\hline 9 & $0 / 2$ & $0 / 2$ & $0 / 2$ & $0 / 2$ & 822 & 62 \\
\hline 10 & $0 / 2$ & $0 / 2$ & $0 / 2$ & $0 / 2$ & 509 & 17 \\
\hline
\end{tabular}

Abbreviations : LDH, lactate dehydrogenase ; ADA, adenosine deaminase ; conv, conventional PCR; nested, nested PCR

were positive by MPB70 PCR than in the patients who were negative by that PCR. In samples from patients with lung cancer, no band was detected by PCR for either the MPB70 gene or the 16S rRNA gene.

\section{Discussion}

We previously described 2 PCR methods ${ }^{16)}$ that amplify the bovine tuberculous MPB 70 gene and the mycobacterial 16S rRNA gene for use in detecting $M$. tuberculosis and mycobacteria, in sputum, respectively. This combination of PCR abilities was available to differentiate $M$. tuberculosis from nontuberculosis mycobacteria. In the previous study, we investigated the correlation between results obtained by the conventional PCR and bacteriological methods in 311 samples of sputum from cases of suspected mycobacteriosis. The PCR method detected 12 cases of infection with $M$. tuberculosis and 4 cases of infection with atypical mycobacteria in 17 specimens that were positive by bacteriological methods, but failed to do so in one case. Among the 294 specimens that were found to be negative by bacteriological methods, the PCR method detected 13 and 8 cases of and atypical mycobacteria, respectively. These results were confirmed by use of commercial DNA probes or by investigation of the clinical background of the patients. The PCR method did not detect mycobacterial DNA in 197 samples of sputum from normal subjects not suspected of having mycobacteriosis. These results indicated that our previous methods of PCR are highly specific for $M$. tuberculosis and mycobacteria, respectively, and are also sensitive enough to detect small numbers of copies of mycobacterial DNA in sputum, which could not be detected by bacteriological methods. In this study, we extended our previous method of PCR and developed a more sensitive and specific PCR protocol, i.e., nested PCR, in which the outer primers were the same as those used in previous PCR methods. Figure 1 shows that nested PCR for both the rRNA and MPB70 genes was at least 10 times more sensitive than conventional PCR and could detect as few as 2 copies of mycobacterial DNA. therefore, the sensitivity of nested PCR in this study is at least 10 times more sensitive than that of the previous study. Using this very snesitive method, we investigated pleural fluids in which bacteriological methods did not detect mycobacteria for the presence of mycobacterial DNA, and evaluated the usefulness of nested PCR.

Table 2 shows that although conventional PCR did not yield positive results, nested PCR showed 
3 patients to be positive for $16 \mathrm{~S}$ rRNA, and that 2 of these 3 patients were also positive for MPB70. In each of these 2 patients, 1 of 2 different samples yielded a positive result by both MPB70 and 16 S rRNA PCR, while the other sample gave a negative result with both methods of PCR. We propose 2 reasons for the discrepant results in 2 samples from the same patient, and for the low prevalence (20\%) of $M$, tuberculosis DNA in pleural fluids from patients with pulmonary tuberculosis that was definitely diagnosed by sputum culture. The first reason is that most of the DNA in pleural effusion was already degraded and inappropriate for PCR. The second is that the reaction of the host against mycobacteria may be more important than the mycobacteria themselves in the pathogenesis of tuberculous pleuritis.

Using conventional PCR and Southern blot hybridization, Pao et al. ${ }^{11)}$ found $M$. tuberculosis in 8 of $37(22 \%)$ samples of pleural effusion, while mycobacterial culture failed to detect any mycobacteria in the samples. All the specimens they tested had been collected from patients with clinical signs of tuberculosis, including characteristic radiographs or typical clinical manifestations of the disease, or a positive history of exposure to tuberculosis, an actual history of tuberculosis, and/or clinical response to anti-tuberculosis chemotherapy. In the present study, the diagnosis of pulmonary tuberculosis were all confirmed by sputum culture. Although there may be some differences between this study and that of $\mathrm{Pao}$ et al. in the reliability of clinical diagnosis of pulmonary tuberculosis, we demonstrated almost the same rate of positivity.

Nested PCR showed that 1 of the 3 patients who were positive for 16S rRNA was negative for MPB70. Mycobacteria other than $M$. tuberculosis may be present in pleural effusion obtained from patients with pulmomary tuberculosis or the number of compies of $M$. tuberculosis DNA was too low for MPB70 PCR. It is unlikely that the positive results were caused by contamination, because negative controls run with each batch of samples failed to detect any contaminating DNA, and the results of PCR for 20 specimens from patients with lung cancer, including 8 specimens from 1 patient that were tested twice, were all negative.

In summary, we have shown that mycobacteria can be detected in pleural effusion by PCR carried out with 4 sets of nested primers and by simple visualization in agarose gels. For samples of pleural effusion, PCR analysis should be repeated or carried out on separate samples from the same individual, because the number of copies of mycobacterial DNA present is usually very low if the culture is negative. The sensitivity of this method may be improved by increasing the amount of pleural effusion from which DNA is extracted. We speculate that the reaction of the host against mycobacteria may be more important than the mycobacteria themselves in the pathogenesis of tuberculous pleuritis.

\section{References}

1) Sahn, S.A.: The pleura. Am. Rev. Respir. Dis. 138: 184-234, 1988.

2) Berger, H.W. \& Meija, E.: Tuberculous pleurisy. Chest 63: 88-92, 1973.

3) Saiki, R,K., Gelfand, D.H., Stoffel, S., Scharf, S.J., Higuchi, R., Horn, G.T., Mullis, K.B. \& Erlich, H.A.: Primerdirected enzymatic amplification of DNA with a thermostable DNA polymerase. Science 239: 487-491, 1988.

4) Hance, A.J., Grandchamp, B., Lévy-Frébault, V., Lecossier, D., Rauzier, J., Bocart, D. \& Gicquel, B.: Detection and identification of mycobacteria by amplification of mycobacterial DNA. Mol Microbiol 3: 843-849, 1989.

5) Brisson-Noël, A., Gicquel, B., Lecossier, D., Lévy-Frébault, V., Nassif, X. \& Hance, A.J.: Rapid diagnosis of tuberculosis by amplification of mycobacterial DNA in clinical samples. Lancet 332: 1069—1071, 1989.

6) Patel, R.J., Fries, J.W.U., Piessens, W.F. \& Wirth, D.F.: Sequence analysis and amplification by polymerase chain reaction of a cloned DNA fragment for identification of Mycobacterium tuberculosis. J. Clin. Microbiol. 28: $513-518,1990$.

7) Böddinghaus, B., Rogall, T., Flohr, T., Blöcker, H. \& Böttger, E.: Detection and identification of mycobacteria by amplification of rRNA. J. Clin. Microbiol. 28: 1751-1759, 1990.

8) Sjöbring, U., Mecklenburg, M., Andersen, A.B. \& Miörner, H.: Polymerase chain reaction for detection of 
Mycobacterium tuberculosis. J. Clin. Microbiol. 28: 2200-2240, 1990.

9) Shanker, P., Manjunath, N., Lakshmi, R., Aditi, B. \& Shriniwas P.S.: Identification of Mycobacterium tuberculosis by polymerase chain reaction. Lancet. 335: 423, 1991.

10) Cousins, D.V., Wilton, S.D. Francis, B.R. \& Gow, B.L.: Use of polymerase chain reaction for rapid diagnosis of tuberculosis. J. Clin. Microbiol 30: 255-258, 1992.

11) Pao, C.C., Yen, T.S.B., You, J.B., Maa, J.S., Fiss, E.H. \& Chang, C.H.: Detection and identification of Mycobacterium tuberculosis by DNA amplification. J. Clin. Microbiol 28: 1877-1880, 1990.

12) De Wit, D., Steyn, L., Shöemaker, S. \& Sogin, M.: Direct detection of Mycobacterium tuberculosis in clinical specimens by DNA amplification. J. Clin. Microbiol. 28: 2437-2441, 1990.

13) Shanker, P., Manjunath, N., Mohan, K.K., Prasad, K., Behari, M. \& Shrini, W.A.S.: Rapid diagnosis of tuberculous meningitis by polymerase chain reaction. Lancet. 337: 5-7, 1991.

14) Thierry, D., Brisson-Noël, A., Lévy-Frébault, V., Nguyen, S. \& Guesdon, J-L, Giequel, B.: Characterization of a Mycobacterium tuberculosis insertion sequence, IS6100, and its application in diagnosis. J. Clin. Microbiol 28: 2668-2673, 1990 .

15) De Lassence, A., Lecossier, D., Pierre, C., Cadranel, J., Stern, M. \& Hance, A.J.: Detection of mycobacterial DNA in pleural fluid from patients with tuberculous pleurisy by means of the polymerase chain reaction: comparison of two protocols. Thorax 47: 265-269,1992.

16) Kusunoki, S., Murata, Y., Minamide, W., Uchida, K., Miura, H. \& Ezaki, T.: Rapid and direct detection of Mycobacterium tuberculosis complex and mycobacteria in sputum by advanced method. PCR, J. Jpn. Assoc. Infect. Dis. 66: 1682-1691, 1992.

17) Albert, J. \& Fenyö, E.M.: Simple, sensitive, and specific detection of human immunodeficiency virus type 1 in clinical specimens by polymerase chain reaction with nested primers. J. Clin. Microbiol 28: 1560-1564, 1990 .

\title{
胸水中抗酸菌 DNA の検出における nested polymerase
}

\section{chain reaction の有用性の検討}

\author{
${ }^{1)}$ 九州大学医学部胸部疾患研究施設 \\ 2)塩野義製薬株式会社臨床検査部シオノギバイオメディカルラボラトリーズ \\ 3)北九州市立療養所松寿園 \\ 桑野 和善 ${ }^{1)}$ 南出和喜夫 ${ }^{2)}$ 楠 伸治 $^{2)}$ 五十君裕玄 ${ }^{2)}$ \\ 藤木 哲郎 ${ }^{3)}$ 松葉 健一 ${ }^{3)}$ 原 信之 ${ }^{1)}$
}

\section{要旨}

臨床検体における抗酸菌の検出に打いては polymerase chain reaction が最も鋭敏な検查で ある.しかし，結核性胸水の診断における PCRの 有用性についての報告は少ない。我々は, bovine tuberculous MPB70gene と mycobacterial 16S rRNA gene を, 鋭敏で特異的な nested PCR 法を 用いて増幅し，臨床検体における結核菌と抗酸菌 の検出に用いた.まず，既知の量の抗酸菌の DNA を用いて nested PCRの検出感度を検討した結 果, bevine tuberculous MPB70 gene, mycobacterial 16S gene共に, 少なくとも 2 コ ピーあれば検出可能であった，さらに，喀痰培養 にて結核と診断した症例のうち, 胸水の培養で菌
が検出されなかった10症例の胸水より抽出した DNA を用いて臨床的有用性について検討した. その結果 nested ではない通常の PCR は全く検 出できないのに対して, nested PCRによって, mycobacterial 16S rRNA は10例中 3 例, bovine tuberculous MPB70 gene は10例中 2 例に検出さ れた.また, 肺癌の胸水にはいずれの PCR によっ ても全く検出されなかった。したがって, nested PCR は, 培養が陰性であっても, 胸水中の抗酸菌 を迅速に検出することが可能である方法と思われ た。また, 結核性胸膜炎においては, 結核菌自体 の関与より，これに対する反応の方が重要である 可能性が示唆された。 